ارزيابى راندمانهاى آبيارى، كار آيى مصرف و بهرهورى آب در حوضه درياجه اروميه (مطالعه موردى شبكه آبيارى و زهكشى زرينهرود)

رضا جمالى'، سينا بشارت"، مهدى ياسى و افشين اميريور ديلمى

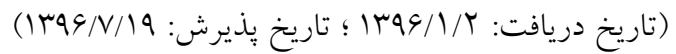

جكيده

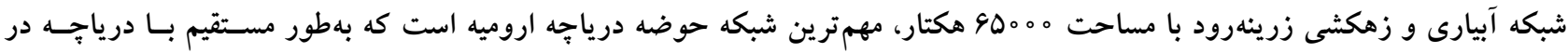

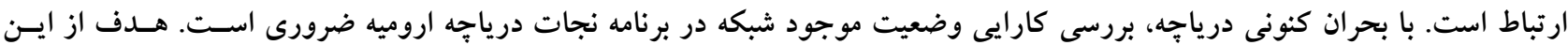

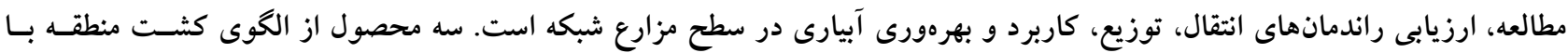

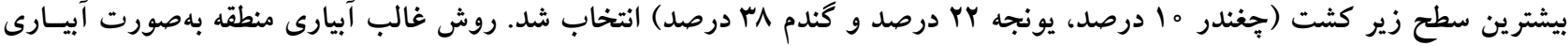



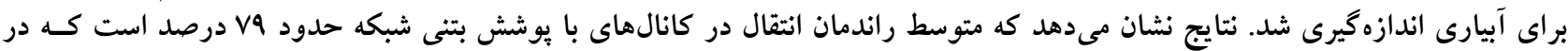

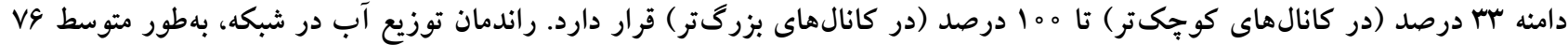

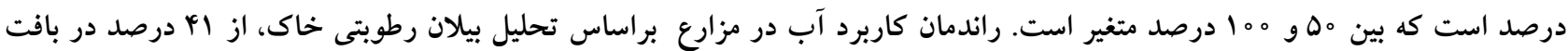

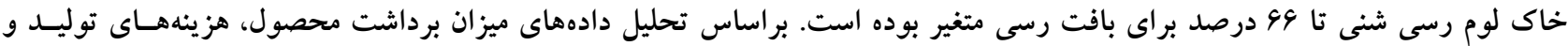

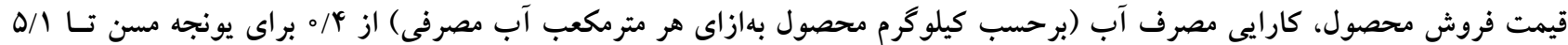

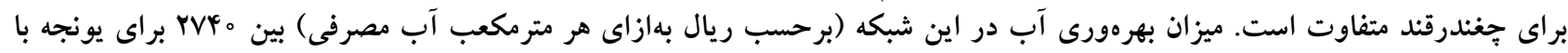



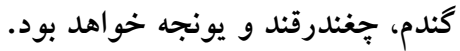

وازمهاى كليدى: آبيارى سطحى، راندمان آبيارى، بيلان رطوبتى، شبكه زرينهرود، درياجه اروميه

ا. كروه مهندسى آب، دانشكده كشاورزى، دانشخاه اروميه

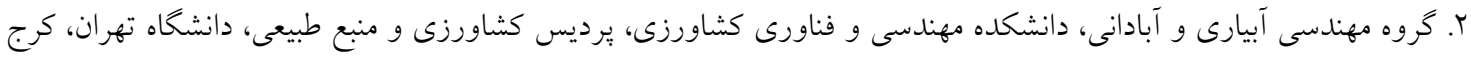

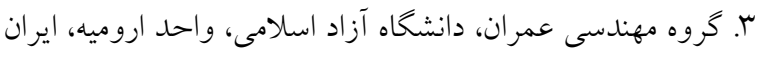

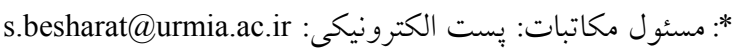


نتايج حاصل از مطالعه آنها نشان داد، بازدهى كاربرد آب آبيارى

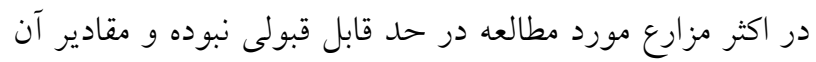

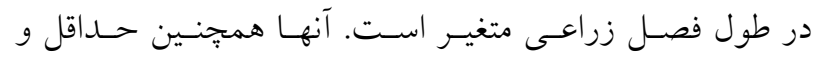

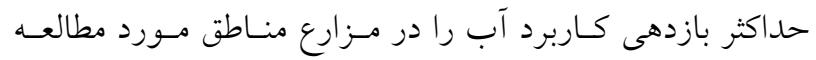

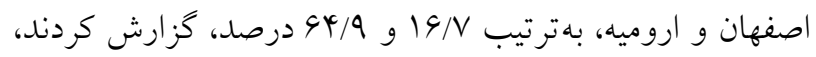
آنان ضعف طراحى و عدم مديريت صحيح آبيارى را دليل عمده

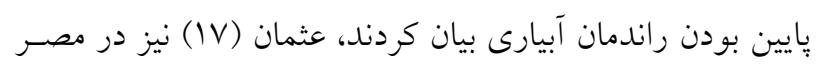

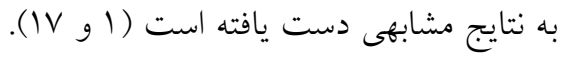


مطالعاتى را در اسـتانهـاى خراسـان، كلسـتان و اصـفهان روى هـ

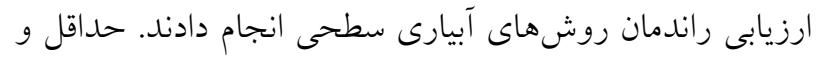

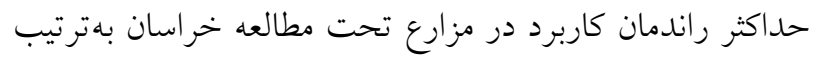



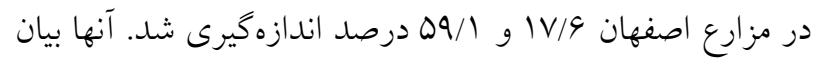
داشتند كه روش آبيارى تأثير بهسزايى در افزايش راندمان آبيارى الفران

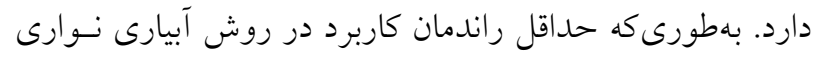

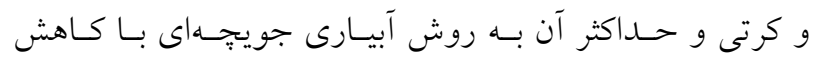

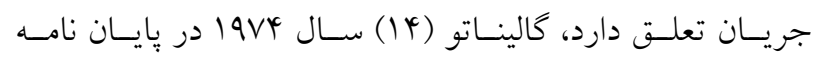
كارشناسى ارشد خود در دانشخاه آيداهو ايالات متحده، به نتايج


سبحانى و دادمهر (Y) در تحقيقى رطوبت خاك را بـهمــت

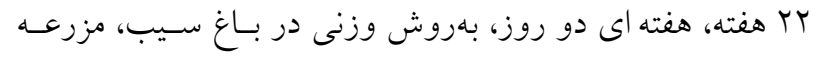

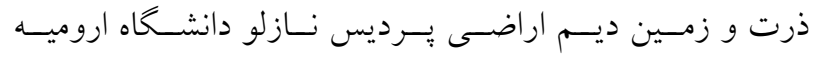

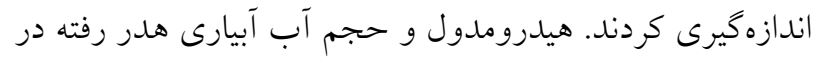


است و اين بدان معنى است كه آب مورد نياز سه سال درختان،

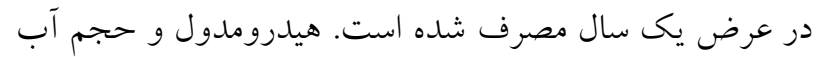



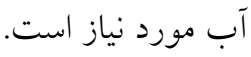

براساس مطالعهاى كه قدمى فيروزآبـادى (9) بـهمنظـور تعيـين كارايى مصرف آب در مزارع سيبزمينى در دشـت قهاونـــ همــــان

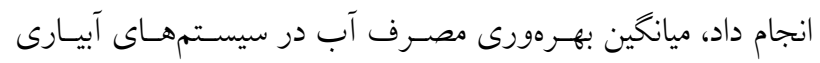

ايران در يك منطقه نيمه خشك واقع شده است و آب مهمتسرين

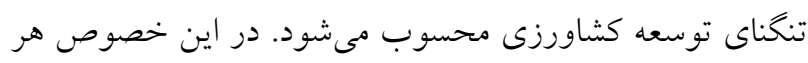

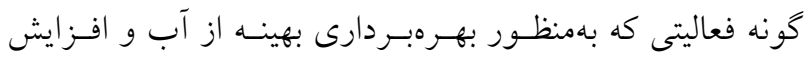



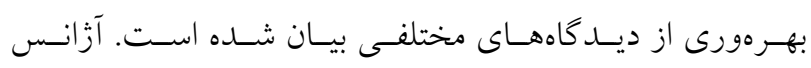

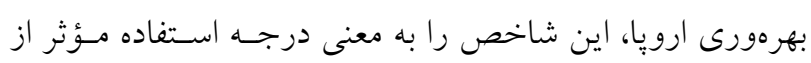



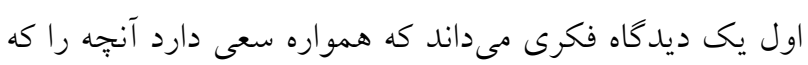

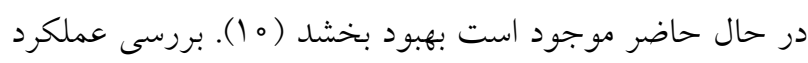

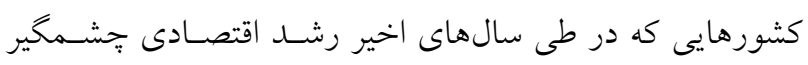



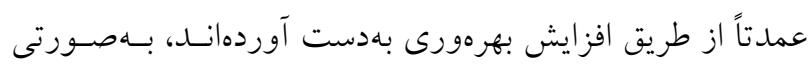



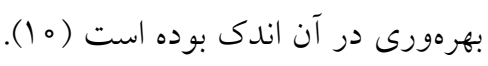

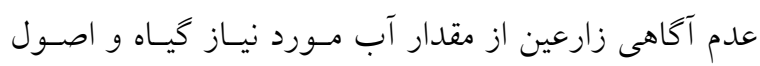

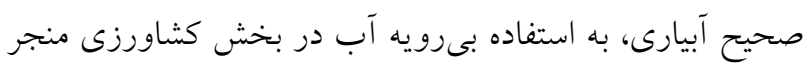

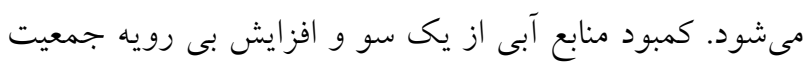

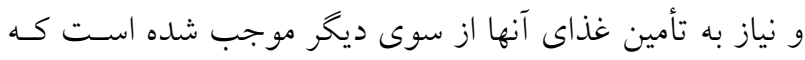

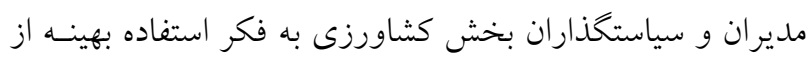

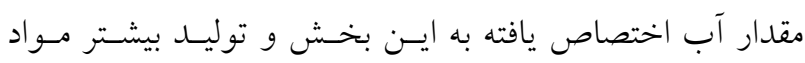
غذايى باشند (V) (v)

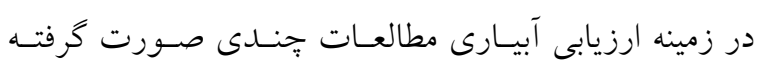

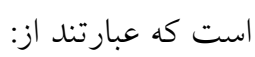

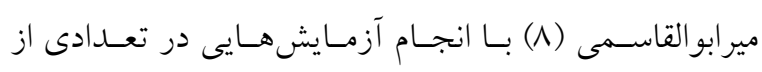





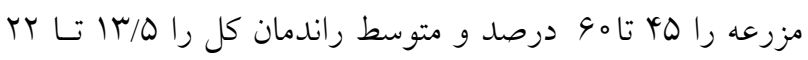
درصد براورد كرد. اسدى و همكاران (1) با مطالعهاى يكسـاله، بـازده كـاربرد آب در روشهاى آبيارى سطحى تحت مــيريت زارعسين را در مناطق كرمان، اصفهان، اروميه و كر گان مورد ارزيابى قرار دادند. 


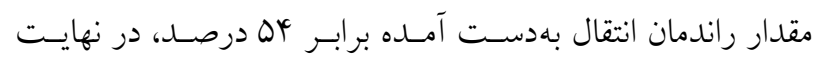
مقدار راندمان كل را هr درصد گزارش كردند.



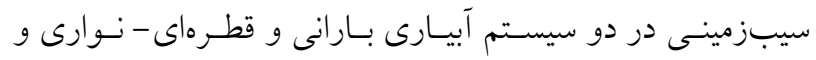



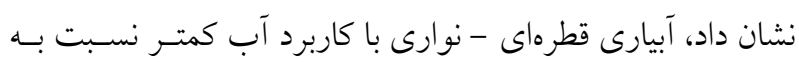

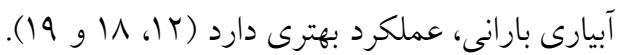

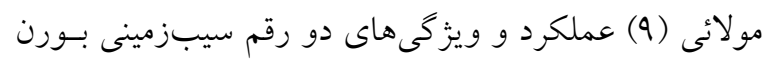



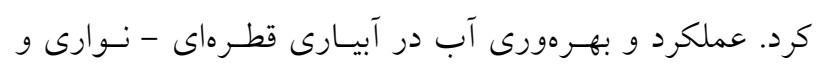



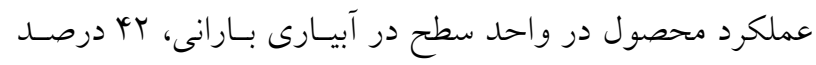
كمتر از آبيارى قطرهاى - نوارى بود.

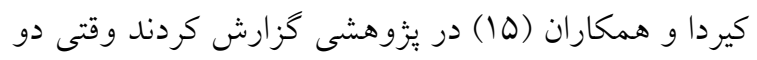

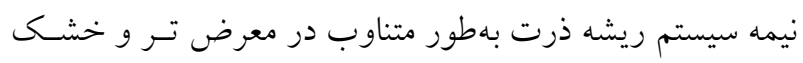

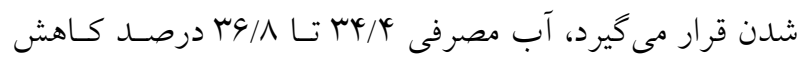

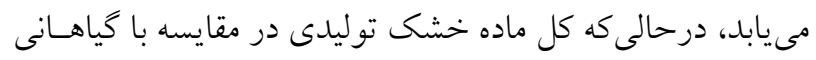

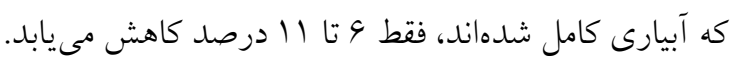

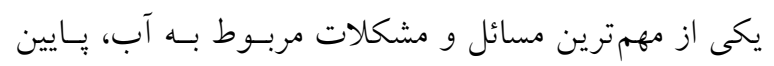

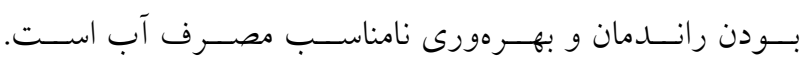



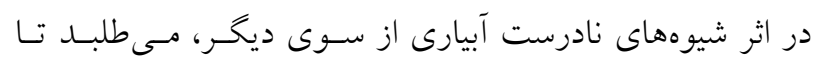







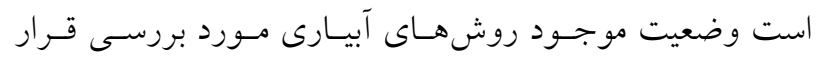





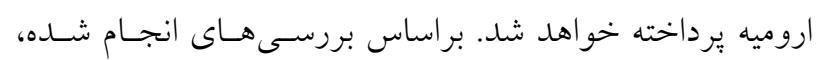

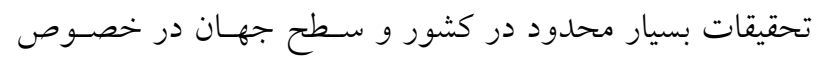



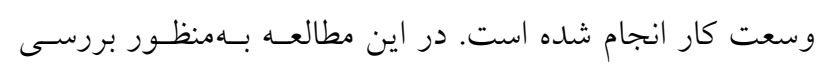

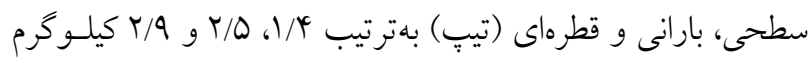

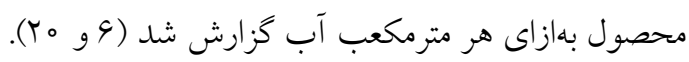





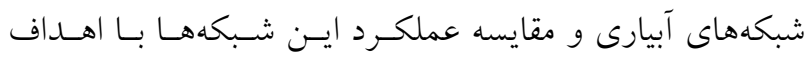

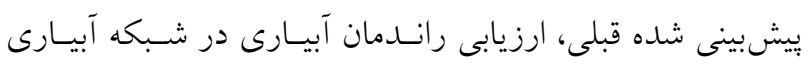

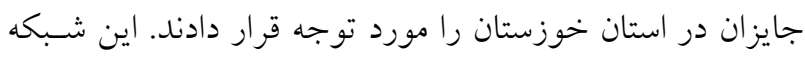
شامل 9000 هكتار سطح ناخالص است كه از رودخانـه مـارون

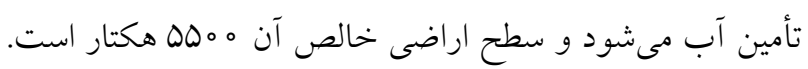

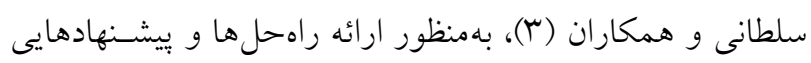

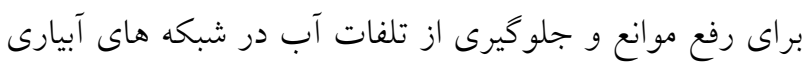

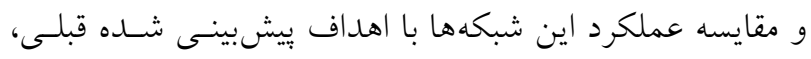

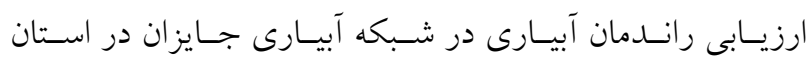

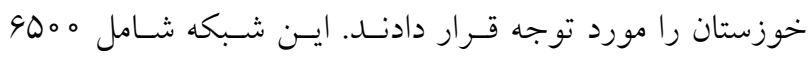

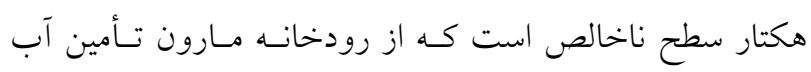



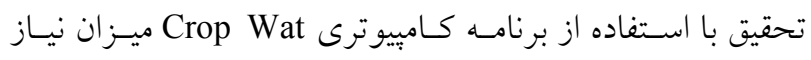

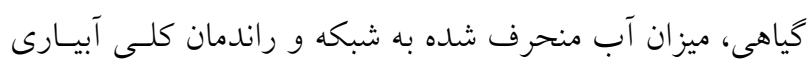

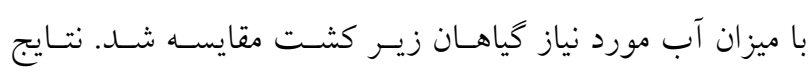

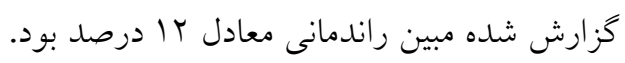

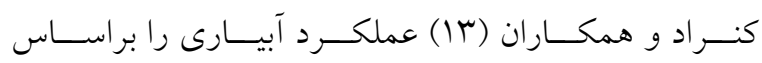

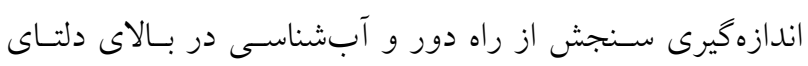

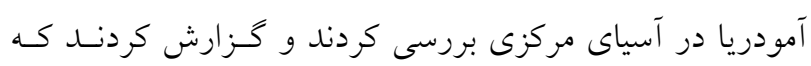

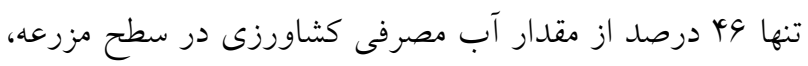
به مصرف توليدات گياهى مىرسد.

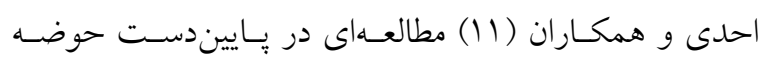

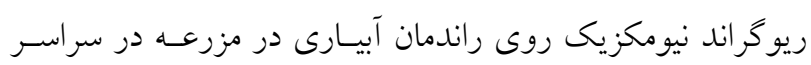

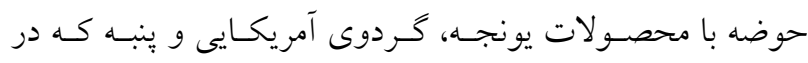





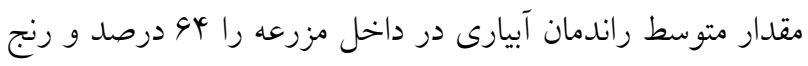

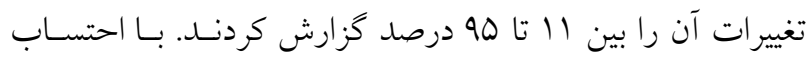



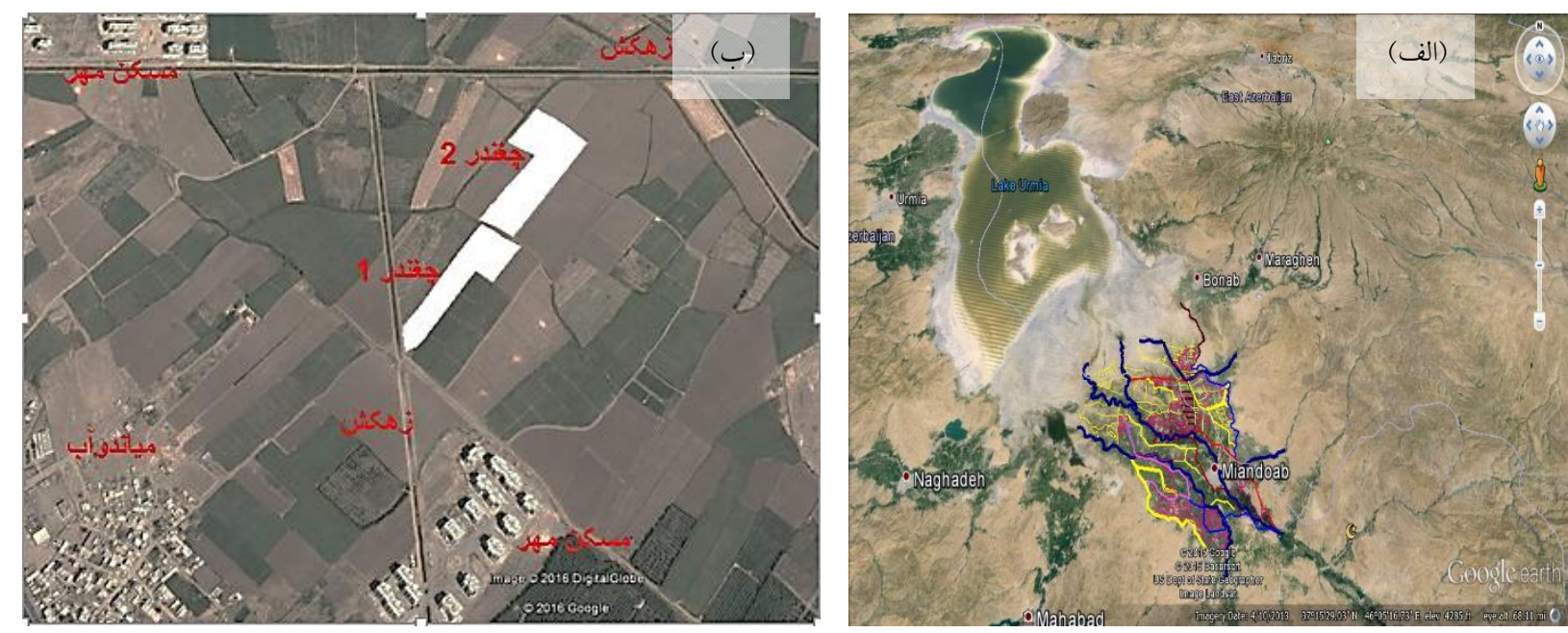

شكل 1. الف) موقعيت شبكه آبيارى و زهكشى زرينهرود در حوضه درياجه اروميه و

ب) نمونه كشت جغندرقند در حاشيه شهر مياندوآب

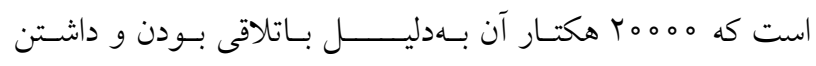
سطح تراز برابر با سـطح درياجـهـ اروميـه قابـل اسـتفاده نيسـت و

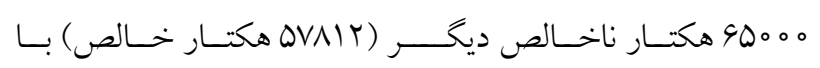
اجـــــراى طرح شبكه آبيارى و زهكشى قابل استغاده شــه اسـت.



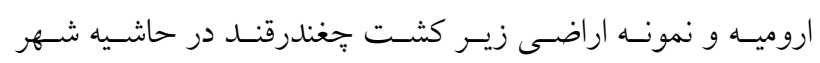
مياندو آب در شكل (1) نشان شده است. در داخل شبكه آبيارى و زهكشى زرينهرود، سه محصول از محصولات اصلى الخوى كشت منطقه شامل جِغندرقنــ، يونجـهـ


دهند، بهعنوان الكوى كشت شبكه انتخــاب شـدند (11). سـبس نه

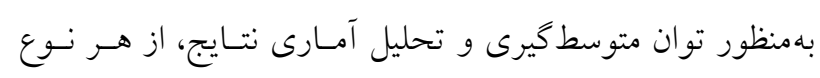


(جهار تكرار آزمايش) بهصورت كاملاً تصـادفى از طريـق امـور

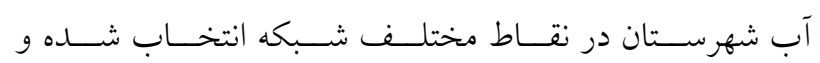
آزمايشهـاى تعيسين رانـدمان كـاربرد آبيـارى روى آنهـا انجـام

الف) عمليات صحر اييى عمليات صحرايى شامل سه مرحله بود:
راندمان كاربرد آب در مزرعه از بيالانبندى رطوبتى خاى مزرعه

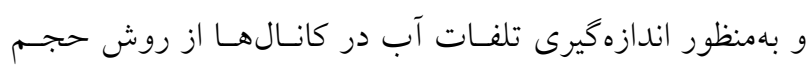
ورودى - خروجى استفاده شد. از آنجـايى كـه شبكه آبيـارى و

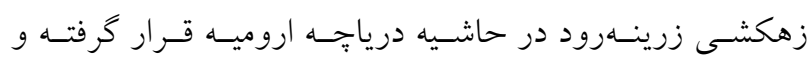



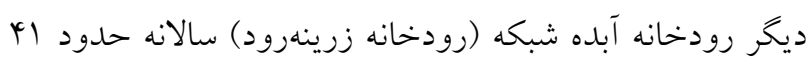
درصد از آب ورودى به درياجٍه اروميه را تأمين كرده است، لـذا بـا بررسى و اطلاع از وضعيت موجود شبكه و راندمانهاى آبيـارى در داخل آن لازم بهنظر مىرسد.

\section{مواد و روشها}

شبكه آبيارى و زهكشى زرينهرود واقع در شمال غربسى ايـران بـين

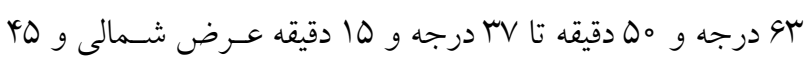
درجه و •ه دقيقه تا وبا درجه و ها دقيقه طول شرقى قـرار كرفتسه

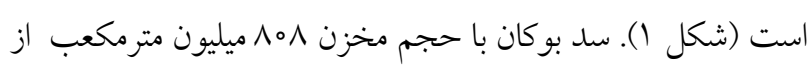
طريق سد انحرافى نوروزلو، دشت را تخذيه مى كند. آب تخليه شـده مئد

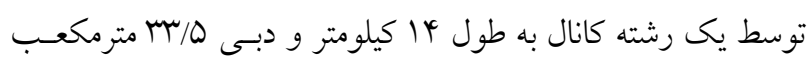
در ثانيه كه ساحل جِّ و يك رشته كانال به طول FV/T كيلـومتر و دبى ه广 مترمكعب در ثانيه كه ساحل راسـت را بوشـش مسى دهنـد، توزيع مىشود. دشت زرينهرود داراى وسعتسى برابر مله هـ هكتـار 


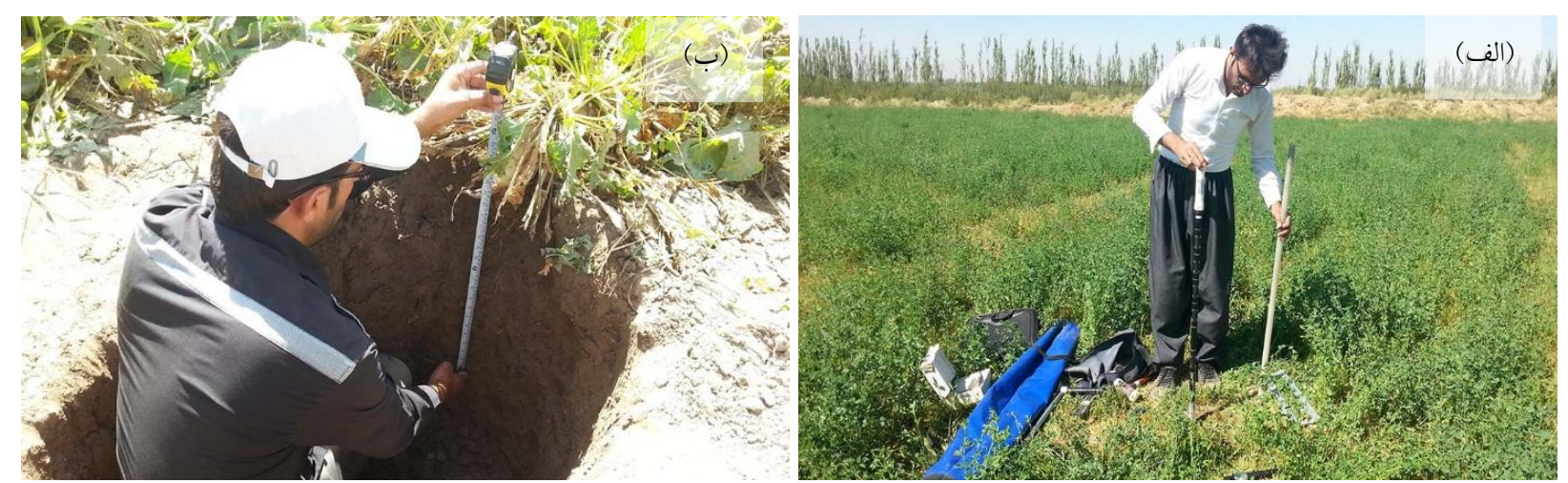

شكل r. الف) اندازهيرى رطوبت خاك در اعماق مختلف بهوسيله رطوبت سنج TDR و ب) اندازهيرى عمق توسعه ريشه
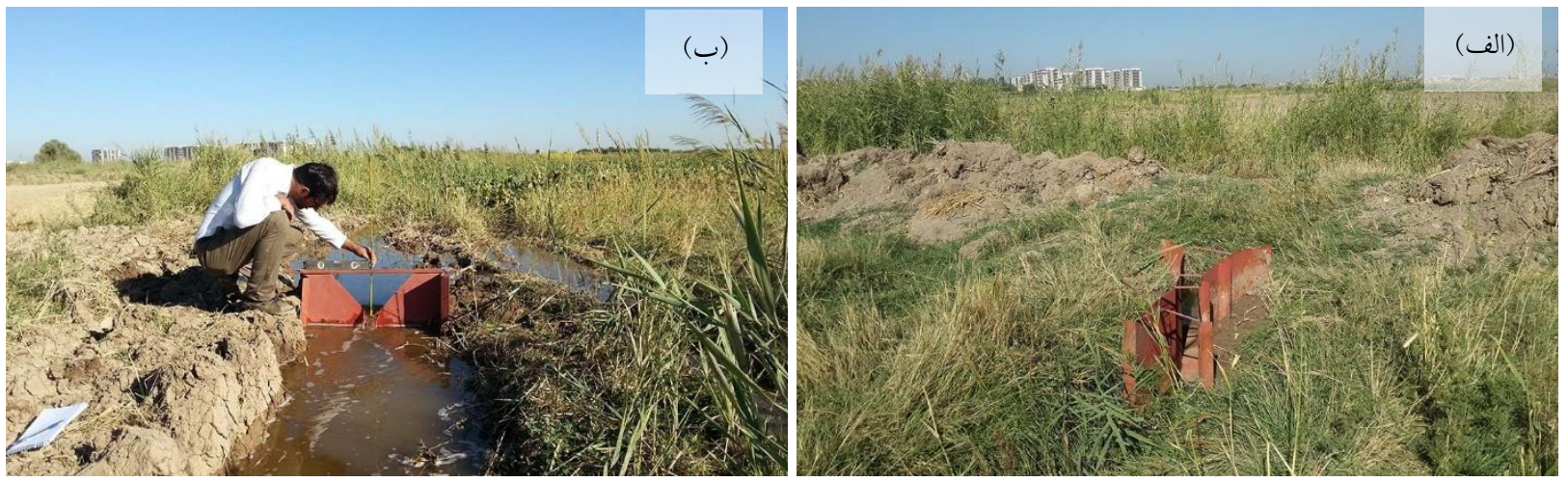

شكل r. الف) ثبت دبى آب آبيارى ورودى بهوسيله بارشالفلوم و ب) ثبت رواناب خروجى از مزارع مورد مطالعه با سر ريز مثلثى

در طول مدت زمان آبيـارى، حجـم آب وارد شــه بـهـ زمسين و

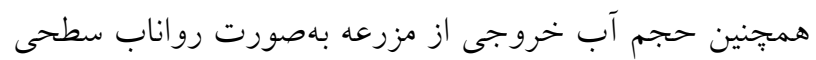
اندازهيرى و محاسبه شدند (شكل بَ).

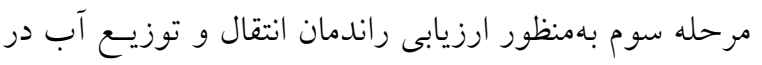
شبكه، از روش حجم ورودى - خروجى، با استفاده از دستئاه

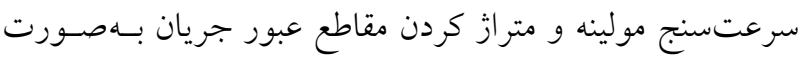
آنى در صحرا و مشخص كردن گرفتكى مقاطع اقدام شد (شكل

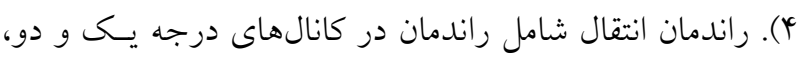
همجنين راندمان توزيع به راندمان در كانـالهـاى درجـه سـه و جهار گفته مىشود. روش ارزيابى راندمانهاى انتقـال و توزيـع

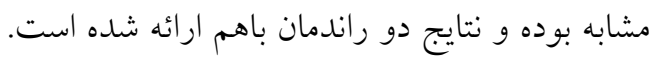







مرحله اول، شامل برداشت نمونه جهت تعيين خصوصسيات

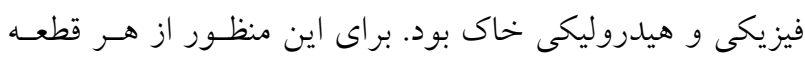



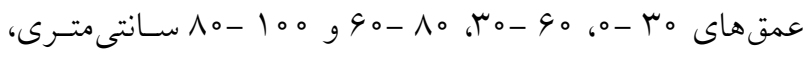
برداشت شد.

مرحله دوم شامل تعيسين رطوبـت خــاك در قبـل و بعـــ از

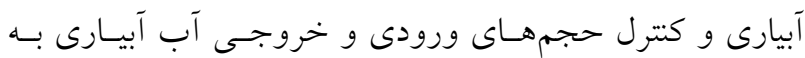

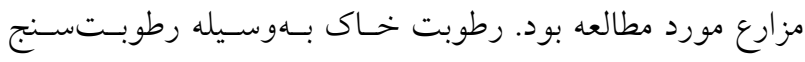

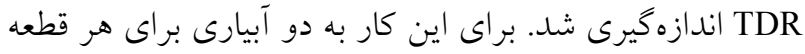



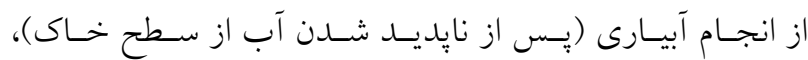
رطوبت يروفيل خاك قرائت شد. عمق توسعه ريشه كياه كشـت

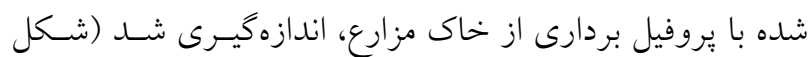

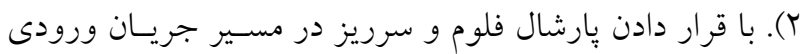





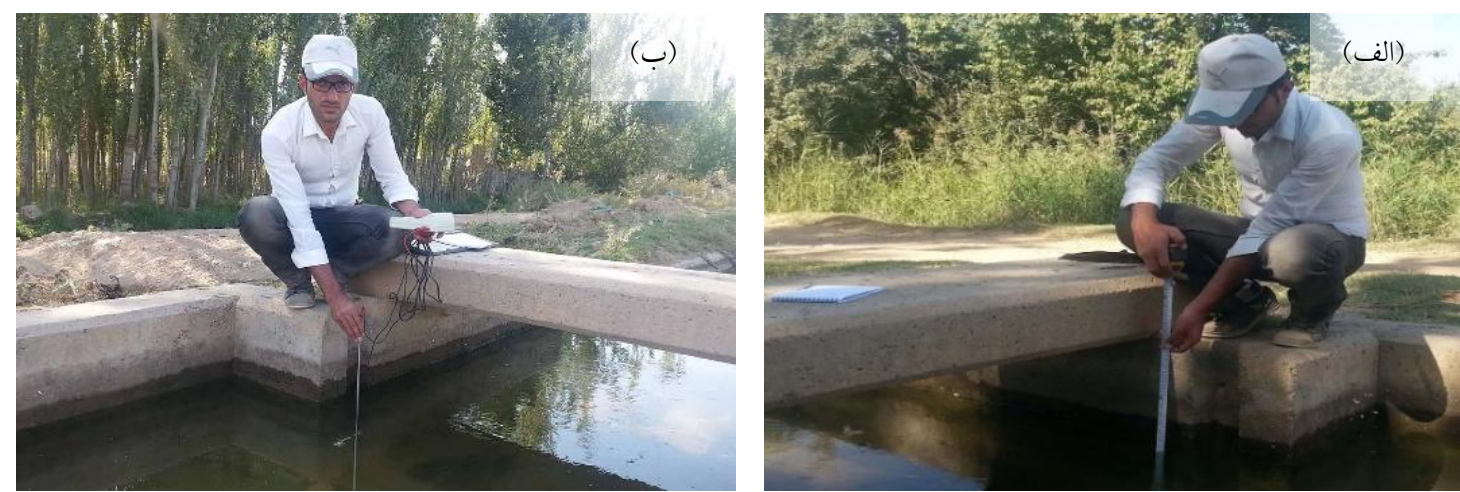

شكل fا. الف) اندازهيرى عمق و هندسه مقاطع عبورى جريان و ب) اندازهيرى سرعت جريان در كانال بهوسيله مولينه

جدول ا. مشخصات هندسى و روش آبيارى مزارع مورد مطالعه

\begin{tabular}{|c|c|c|c|c|c|c|c|c|}
\hline كاربردى آب & كاربردى آب آب & عرض مزرعه & طول مزرعه & نحيوه & منبع تأمين آب & روش آبيارى & محصول نوع & مزرعه \\
\hline TYQTI०V & TGYOVTM & 09 & TVA & سنتى & كانال & نوارهاى شياردار & جغندرقند & 1 \\
\hline TYVTGGY & rqVATYY & 99 & 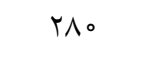 & سنتى & كانال & كرتى شياردار & جغندرقند & r \\
\hline$q Y \circ \circ T \Delta$ & IMItGy. & VI & $v^{4}$ & سنتى & كانال & كرتى & يونجه & r \\
\hline $1001 \wedge \mid 4$ & rYYQTA。 & $\Lambda T$ & 99 & سنتى & كانال & كرتى & يونجه & 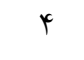 \\
\hline TYYVVq。 & TY1999V & $91 / 0$ & IFY & سنتى & كانال & كرتى & 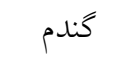 & $\Delta$ \\
\hline r90r०99 & raVIVII & VG & YIV & سنتى & كانال & نوارى انتها بسته & كندم & 9 \\
\hline
\end{tabular}

رطوبت حجمى روزهاى اندازه گيرى، محاسبه و براورد شدند.

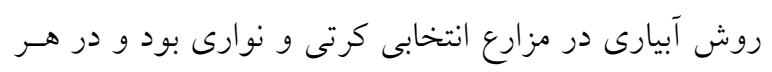

كدام از مزارع، خصوصيات فيزيكى و شيميايى خـاك مزرعسه و

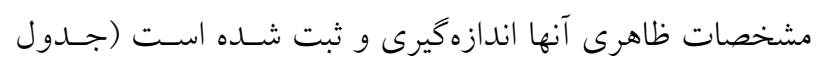

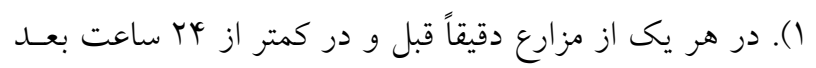

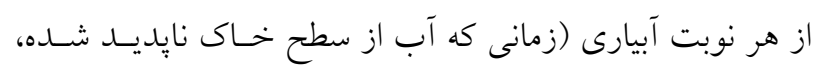
كامل نفوذ كرده يا رواناب شده) رطوبت خاك مزارع با اسـتفاده از دستخاه رطوبت سـنج TDR در دو نقطسه و در عمـق توسـعه ريشه گياه اندازه گيرى شد. مقدار آب ورودى به مزارع بهوسـيله

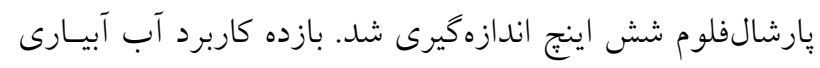
با استفاده از معادله ( ) محاسبه شده است. $\mathrm{Ea}=\frac{\mathrm{d} l}{\mathrm{~d} r}$

$d)=(\theta r-\theta \imath) \times R$
شد. وزن مخصوص حقيقى به روش بيكنومتر تعين شد. هدايت

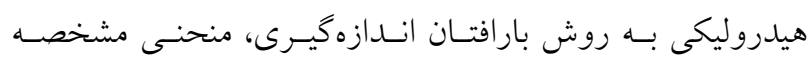
رطوبتى خاى نيز با استفاده از دستخاه صـفحات فشـارى تعيسين


ما و ها بار روى نمونههاى دسـت نخــورده تعيسين شـد. وزن

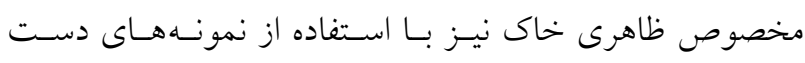
نخورده با مشخص شدن حجم و وزن خشك نمونهها بهدسـت آمد. د) جمعبندى اطلاعات براى ارزيابى

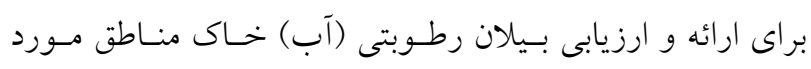

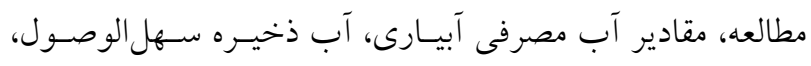
آب ذخيره قابل دسترس و آب اضافى خاك با استفاده از درصد 
جدول r. مشخصات فيزيكى و هيدروليكى خاك مزارع

\begin{tabular}{|c|c|c|c|c|c|c|c|}
\hline رذب (mm ربت قابل & يزمردحى دائم & رطوبت ظرفيت & رطباع & \multirow{2}{*}{$\begin{array}{c}\text { ظاهرى } \\
\left(\mathrm{gr} / \mathrm{cm}^{r}\right)\end{array}$} & \multirow[t]{2}{*}{ بافت خاك } & \multirow[t]{2}{*}{$\begin{array}{c}\text { عمق توسعه ريشه } \\
\text { (cm) }\end{array}$} & \multirow[t]{2}{*}{ شماره مزرعه } \\
\hline & & $\left(\mathrm{m}^{r} / \mathrm{m}^{r}\right)$ & & & & & \\
\hline $9 V / 0$ & $\circ / Y \backslash \Lambda$ &  &.$/ Q 1 V$ & $1 / \mu_{0}$ & رسى & 90 & 1 \\
\hline$M / A^{*}$ & OTKY & $\circ / \mathrm{V} V$ &.$/ 0.1$ & $1 / \mu x$ & رسى & 90 & r \\
\hline $111 / \pi$ & (1/ת & $0 / r \mu q$ & $\circ M V V^{4}$ & $1 / 94$ & لوم رسى شنى & 100 & r \\
\hline $118 / 9$ & OMYY & - MQF & $\circ / 4 \wedge$ & $1 / 09$ & لوم رسى شنى & 100 & r \\
\hline VN/I & $0 / 1 r a$ & $0 / Y N 1$ & $0 / 449$ & $1 / 49$ & لوم رسى & $\Delta \Delta$ & 0 \\
\hline$V \varphi / \Lambda$ &.$/ 110$ & $\circ / T Q 1$ & $0 / 4 \circ \Lambda$ & $1 / 00$ & لوم رسى & $\Delta \Delta$ & 4 \\
\hline
\end{tabular}

آزمايشگاه روى نمونههاى برداشت شده تعيين شدند (جدول Y). در نهايت اندازهكيرىها در شش مزرعه بهصـورت كامـل و

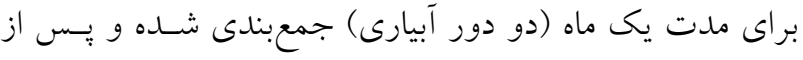



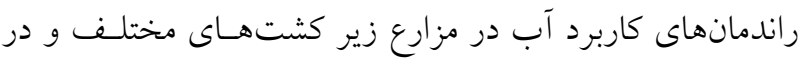


مورد بررسى در جدول (r) ارائه شده است.

نتايج محاسبه راندمان كاربرد آب، براى شـش مزرعـه از مـزارع

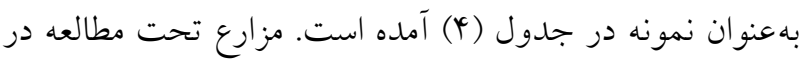

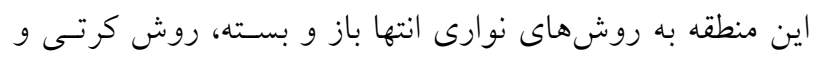
كرتها و نوارهاى شياردار براى كشتهاى رديفى آبيارى شـــه

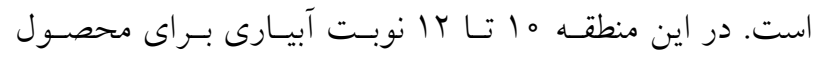

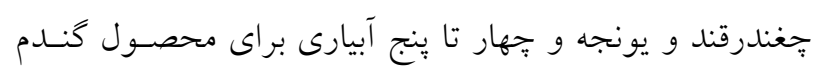

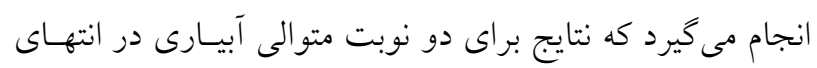
رشد، ارائه خواهد شد. حداكثر راندمان كاربرد در اين مزارع 94

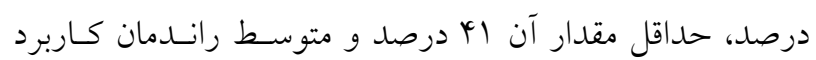
مزارع مو رد مطالعه، مه درصد براورد شده است. همانطور كه از

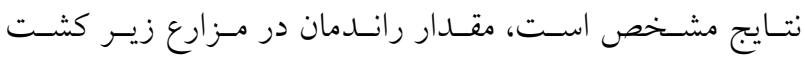
جغندرقند بيشتر از ساير مزارع است كه دليل آن رسى و سنخين

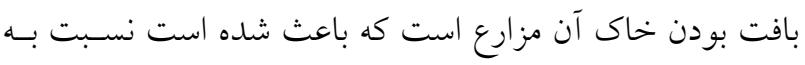

در اين رابطه اd، تغيير ذخيره رطوبتى خاك در ناحيه ريشه كياه در فاصله بين دو نمونهبردارى برحسب سانتى متـر و كلd، مقــار





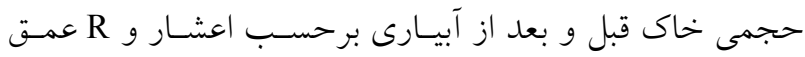
توسعه ريشه برحسب سانتىمتر است.

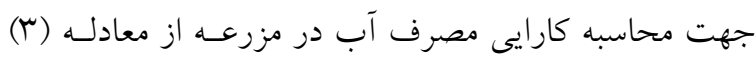

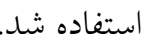

$\mathrm{WUE}=\frac{\mathrm{Y}}{\mathrm{W}}$

در اين رابطه، Wل عملكرد محصول برحسب كيلسوگرم و W كل حجم آب مصرفى بر حسب مترمكعب است.

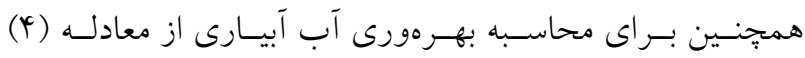

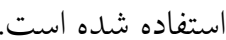
بهر بهورى $=\frac{P}{\mathrm{~W}}$ در اين رابطه، P مقدار سود خالص حاصل از كشـت محصـولى مورد مطالعه است. بهمنظور اطلاع از مقدار حجم آب ذخيره شده در عمق توسـعه



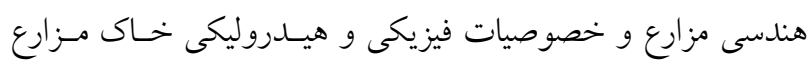

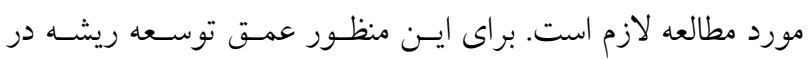




جدول r. مشخصات فنى و هيدروليكى اندازهيرى شده در برخى از كانالهاى مورد بررسى

\begin{tabular}{|c|c|c|c|c|c|c|}
\hline (كول بازه & سرعت متوسط & 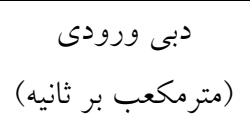 & نوع مقطع & نوع يوشش & تيب كانال & اسم كانال \\
\hline $1 / 419$ &  & $\circ / \wedge \Delta \circ 9$ & ذوزنقهاى & بتنى & درجه دو & نصير كندى \\
\hline I/VYY & $r / T \circ \varphi$ & r/NIV & ذوزنقهاى & بتنى & درجه دو & قشلاق نوروزلو \\
\hline$\circ / V \circ \varphi$ & $0 /$ pqy &.$/ 9190$ & ذوزنقهاى & بتى بن & درجه دو & حسين آباد \\
\hline$\circ / \Lambda$ & $0 / Y \wedge Y$ & o/ KVG & ذوزنقهاى & بتنى & درجه سه & جاده نصير كندى \\
\hline $1 / \mu \wedge \Lambda$ & $0 / 4 \wedge 9$ &.$/ 0 \wedge V$ & ذوزنقهاى & 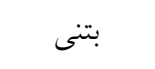 & درجه سه & قره ورن \\
\hline$\circ / \Delta \Delta r$ & $\circ / \mu \vee q$ & $\circ / \mathrm{VV}$. & ذوزنقهاى & بتنى & درجه سه & قشلاق نوروزلو \\
\hline
\end{tabular}

جدول fا. محاسبه و يارامترهاى مربوط به راندمان كاربرد آب آبيارى در مزارع مورد بررسى شبكه آبيارى و زهكشى زرينهرود

\begin{tabular}{|c|c|c|c|c|c|c|c|c|}
\hline \multirow{2}{*}{$\begin{array}{l}\text { كاربرد } \\
\text { راندمان } \\
\text { (\%) }\end{array}$} & ذخيره شده آب & عمق آب آبارى & \multirow{2}{*}{ عمق توسعه } & ربوبت متوسط از آبيارى & \multirow[t]{2}{*}{ رقبل از آبيارى متوسط } & \multirow{2}{*}{ محصول } & \multirow{2}{*}{ نوبيت } & \multirow{2}{*}{ شزرعه } \\
\hline & \multicolumn{2}{|c|}{$(\mathrm{mm})$} & & $\left(\mathrm{m}^{r} / \mathrm{m}^{r}\right)$ & & & & \\
\hline $0 / 9 Y$ & $99 / 4$ & 191 & 90 & $Y Q / r$ & $Y I / D$ & جغندر & 1 & 1 \\
\hline - KV V & $V Y / T$ & lOT & 90 & $x+/ 0$ & $r \Delta / V$ & جغندرقند & r & 1 \\
\hline $0 / 94$ & $91 / 1$ & $14 \lambda$ & 90 & $K Y / \Lambda$ & Tr/V & جغندرقند & 1 & r \\
\hline ס/DYr & $\uparrow \wedge / 1$ & $9 r$ & 90 & $r \circ / \Lambda$ & $\mu_{\circ / \mu}$ & جغندرقند & r & r \\
\hline $0 /$ MY & $101 / 1$ & r. & $1 \circ 0$ & $r T / \mu$ & $1 Y / 9$ & يونجه & 1 & r \\
\hline $0 / 49$ & $\wedge \vee$ & IVA & 100 & $T Y / T$ & $10 / 9$ & يونجه & r & r \\
\hline $0 / 41$ & IYT/A & r99 & $1 \circ 0$ & $r m / q$ & $I T / T$ & يونجه & 1 & t \\
\hline - /OT & $99 / 0$ & 191 & 100 & $T Y / D$ & $10 / \circ Y$ & يونجه & r & r \\
\hline$\circ / \Delta \circ \Delta$ & 94 & 119 & VQ & $4 \circ / 0$ & $10 / 9$ & كندم & 1 & 0 \\
\hline$\circ / 4 V V$ & $\Lambda T / \Delta$ & IVr & VQ & rq & $|V /|$ & كندم & r & 0 \\
\hline OMY & $9 \Lambda$ & 194 & VQ & rV & 19 & كندم & 1 & 4 \\
\hline$\circ / 4 \wedge \varphi$ & $\Lambda \vee$ & 189 & VQ & $r \Delta / \varphi$ & $1 \pi / 0$ & كندم & r & 4 \\
\hline
\end{tabular}

اعم از عدم اطلاع كشاورزان از ميزان رطوبت خــاك در قبـل از


خاى كامل خارج نمى شود، لذا بعد از هر بـار آبيـارى مقـدارى رطوبت در خاك انباشته مىشود، اين رطوبت اوليه در آبيارىهـا رو به افزايش است. تغييرات رطوبت در يـك نمونـه بــروب از زمين زير كشت جغندرقند و يك نمونه از يونجه در شـكل (ه) نمايش شده است.
ساير مزارع نفوذ عمقى كمتر و در نتيجـه ذخيـره بيشـتر داشـته باشد و بهدليل يايين بودن سرعت نفوذ، توزيع سـريعتـر آب در



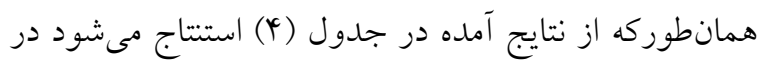
اكثر موارد، مقدار متوسط رطوبت حجمى در قبل از آبيـارى اول كمتر از مقدار آن در آبيارى دوم است كه دليل آن به دو صورت

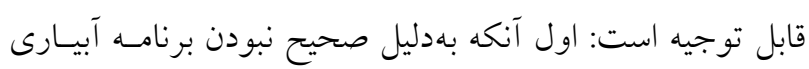



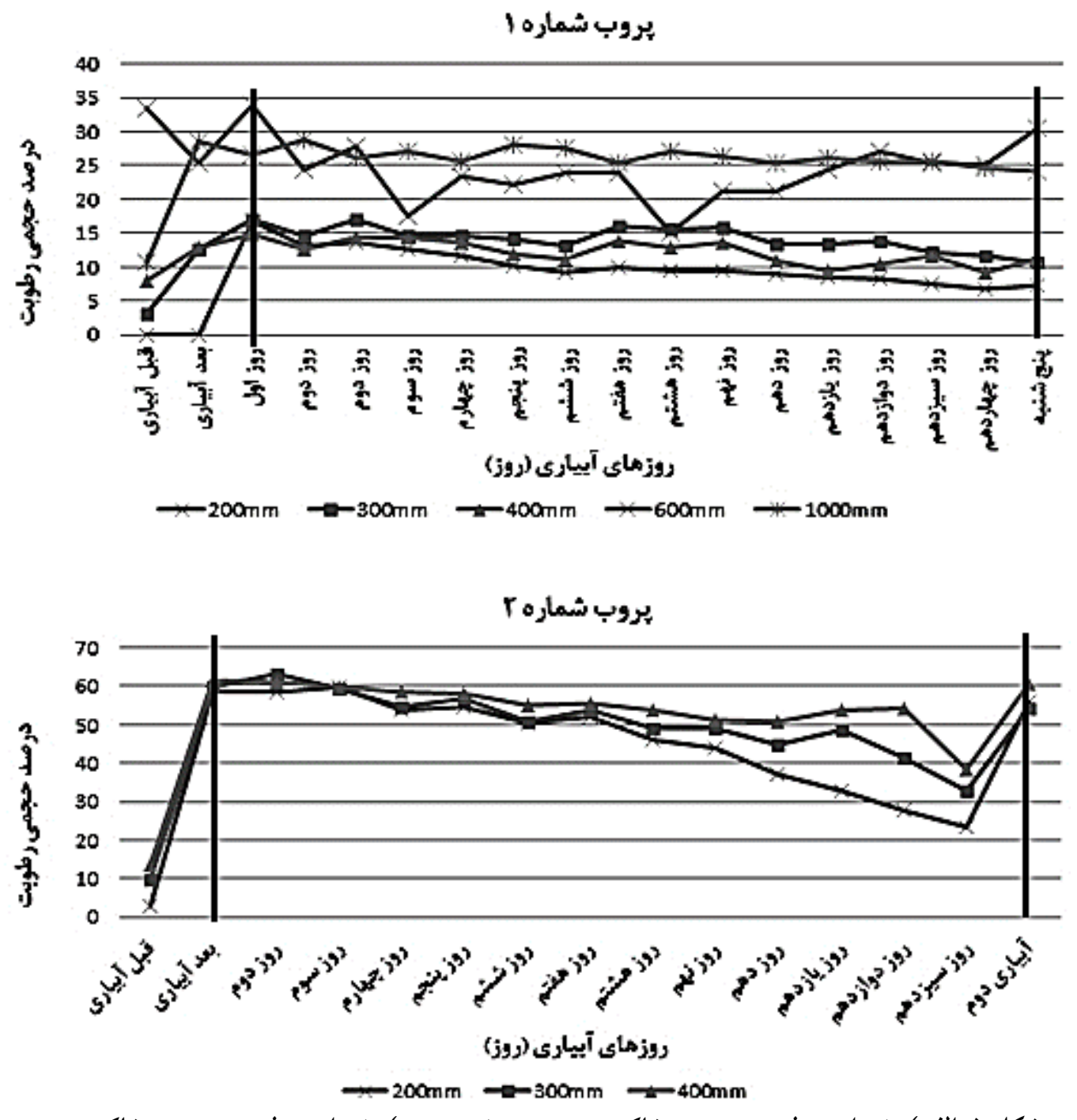



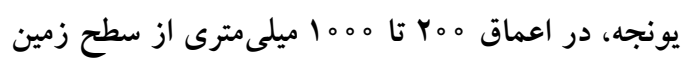

شبكه كه †| تا ها روز به طول مسى انجامـل، رطوبـت خـاك تـا نزديك به رطوبت بزمردكى دائم تخليه مىشود.

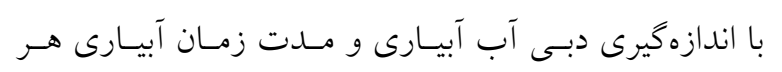
مزرعسه، حجـم آب مصـرفى در طـول فصـل زراعسى محاسـبه،

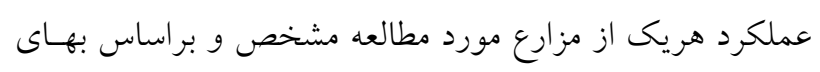
فروش واحد محصول توليدى و اعمال مقدار هزينههاى صورت

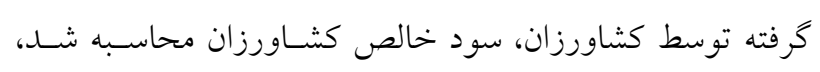

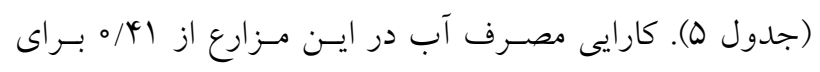

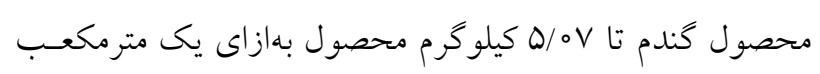

دوم اينكه دور آبيارىها ثابت نبوده و تابع در دسترس بودن آب





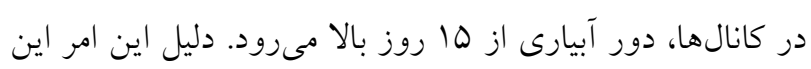




در دوره rا روزه وجود آب در كانالها، دو بار آبيارى صسورت مى كيرد كه فاصله آبيارىها كم بوده و رطوبت قبل از آبيارى در

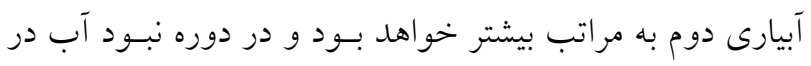


جدول ه. مقادير عملكرد محصول، حجم آب مصرفى در طول دوره رشد و سود حاصل از مصرف آب

\begin{tabular}{|c|c|c|c|c|c|c|}
\hline \multirow{2}{*}{ حجم آب مصرفى } & \multirow{2}{*}{ تعداد آبيارى } & سود خالص & سود ناخالص & بهاى واحد هزار & \multirow{2}{*}{ عملكرد محصول } & \multirow{2}{*}{ شزماره } \\
\hline & & & (ريال) & & & \\
\hline Vעrס & r & TYVT००००。 & rGYQD०००० & TVOO & Ir山०。 & 1 \\
\hline roYAT & 11 & TMD०9०००० & KYYYOO०००० & YYOO & $1 \wedge 0000$ & r \\
\hline IrarA & ir & $\vee \circ \circ \circ \circ \circ \circ$ & WVa o०o。 & VGo。 & 1० ro० & r \\
\hline r)1999 & 11 & 90000000 & GVYYIOO० & $\vee \Delta V^{\circ}$ & $\wedge 9 \mu_{0}$ & r \\
\hline$q r r q$ & r & YqlYooo。 & $0 \wedge 990 \circ \circ \circ$ & 11000 & مانD. & 0 \\
\hline $14 \circ 90$ & $\Delta$ & 99990000 & l०90YVQ०० & 11\%ם。 & $990^{\circ}$ & 4 \\
\hline
\end{tabular}

جدول و. عملكرد، كارايى مصرف آب و بهرهورى آب آبيارى در مزارع مورد مطالعه شبكه آبيارى و زهكى زرينهرود

\begin{tabular}{|c|c|c|c|c|c|}
\hline 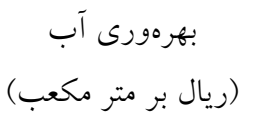 & (كيلو كرم بر مترمكعرف آب & $\begin{array}{c}\text { راندمان كاربرد } \\
\text { (درصد) }\end{array}$ & حجم آب مصرفى (مترمكعب) & عملكرد محصول & شماره مزرعه \\
\hline GNIT & $r / 0 \varphi^{4}$ & $\Delta \Delta$ & rmV & $\mid r \Delta \circ \circ \circ$ & 1 \\
\hline G9TD & $Q / \circ V$ & 09 & roYAT & $1 \wedge 0000$ & r \\
\hline$\Delta \& \backslash Q$ & - /va & 49 & IrGKA & I०TO० & r \\
\hline rVYo & $0 / 41$ & ev & r 1199 & $\wedge q \mu_{0}$ & r \\
\hline DrgD & $\circ / \Delta \Delta$ & 49 & $q$ qrq & DIr. & 0 \\
\hline $9 \wedge 91$ & $0 / 99$ & id & 14090 & $990^{\circ}$ & 9 \\
\hline
\end{tabular}


اصـفهان و كلسـتان بـهــورت كامـل همخــوانى دارد و نتـايج مشابهى برداشت شده اسـت. از طرفى ايـن مقـدار بــايينتــر از


حوضه ريو گراند نيومكزيكوسيتى است كه آنها متوسط رانـدمان كاربرد را بو درصد كزارش كردهاند. رانـدمان انتقـال و توزيـع



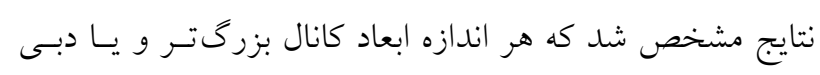
عبـورى از كانـال بيشـتر بــود، رانـــــان انتقــال از وضـعيت مطلوبترى برخوردار بود، براى بهتر روشن شدن اين موضـوع، راندمان انتقال كانالها را يكبار در مقابل نسبت دبى عبورى بـه بيشترين دبى و يكبار در مقابل نسبت ابعاد كانال، به بزرگترين سطح مقطع جريان رسم شد (شكل 9).
آب مصرفى براى جغنندرقند متغير است. بهـرهورى آب آبيـارى

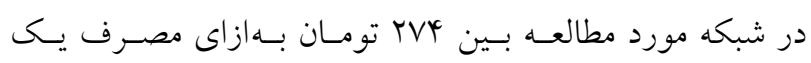

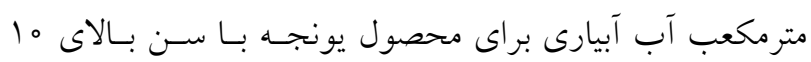
سال تا مو9 تومان براى محصول گندم متغير بود (جدول 9).

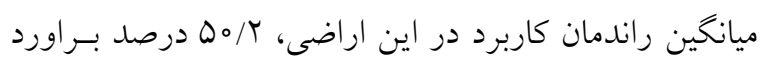

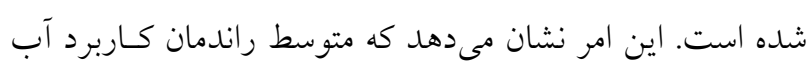
آبيارى در اكثر مزارع مـورد مطالعـه نسـبت بـه ميـانخين ارقـام

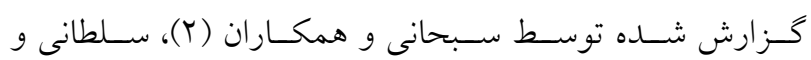
همكاران (r) و همجنين rV د درصد براى كشور توسط عباسى و همكاران (Y)، بيشتر بوده است. از طرفى ايسن مقـدار بـا نتـايج سهرابى و كشاورز هV Iا، براى جغنندرقنـد، ميرابولقاسـمى (A)، براى آبيارى سـنتى دشـتهــاى خوزسـتان، تبريسز و كرمانشـاه، اسدى و همكاران (1)، براى مناطق كرمـان، اصـفهان، اروميـهـ و 
جدول V. راندمان انتقال و توزيع كانالهاى بتنى داخل شبكه آبيارى زرينهرود

\begin{tabular}{|c|c|c|c|c|}
\hline راندمان در طول مورد نظر (درصد) & 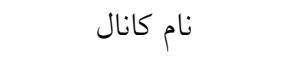 & طول كانال (متر) & 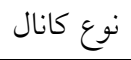 &  \\
\hline سץ & بغل باغ سردار & $1 K 19$ & درجه دو & $\mathrm{GrCl}$ \\
\hline 94 & 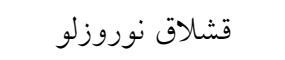 & IVYK & درجه دو & GrCY \\
\hline 100 & حسين آباد بازه اول & qVG & درجه دو & $\mathrm{GrCr}$ \\
\hline $9 \circ$ & حسين آباد بازه دوم & $V \circ 9$ & درجه دو & GrCY \\
\hline Q० & بغل جاده نصير كندى & $\wedge \circ \circ$ & درجه سه & $\mathrm{GrCl}^{\mathrm{C}}$ \\
\hline 100 & بعد مقسم رو به جنوب & IrMA & درجه سه & $\mathrm{GrCr}$ \\
\hline$\wedge r$ & بغل كانال اصلى & ґฯ & درجه سه & $\mathrm{GrCr}^{\mathrm{L}}$ \\
\hline$v^{4}$ & قشاق نوروزلو & DQT & درجه سه & $\mathrm{GrCl}^{4}$ \\
\hline
\end{tabular}


شكل 9. الف) تغييرات راندمان انتقال به مساحت نسبى سطح مقطع جريان و ب) تغييرات راندمان انتقال آب كانال به دبى نسبى عبورى

همجنين كيردا و همكاران (10) كزارش كردند كه با هس درصـد

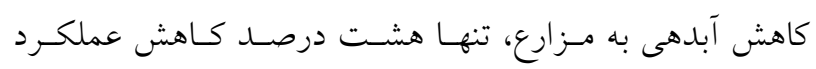
محصول رخ داده است. با اين وجود بهمنظـور صـرفهجـويى در مصرف آب كشاورزى شبكه، مىتوان از تنش كمآبى با طـولانى

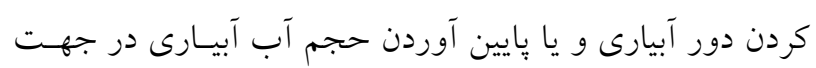
بالابردن راندمان كاربرد با ثابت نخه داشتن عملكرد، به بـالابردن كارايى مصرف آب، بهرهورى مصرف آب و صرفهجويى بيشـتر در مصرف آب كشاورزى كمك كرد.

\section{تتيجحه كيرى}

مقدار راندمان انتقال آب كانـالهـاى يوشـش شـــه شـبكه آبيـارى و

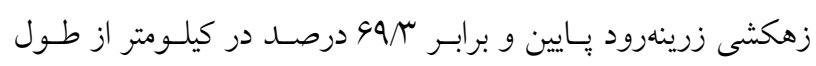
كانال اندازهيرى و محاسبه شد. بيشتر اتلاف آب در كانالهاى درجـهـ
نتـايج يـزَوهش قـدمى فيروزآبـادى و سـيدان (V) نشـان داد در مزارع شيارى با انتهاى بسته بهدليل نبود رواناب، راندمان كاربرد

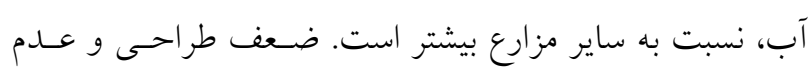

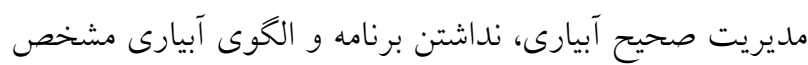

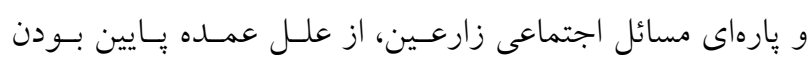
راندمان آبيارى در منطقه تحت مطالعه است. درحالى كه در ايسن يزوهش، از آنجـايى كـه منطقـه داراى شـبكه زهكشـى بـوده و رواناب خروجى مزرعه مستقيم به داخل زهكش مسىريـزد، لــذا مقدار رواناب خروجى از مزرعه، از حجم آب كاربردى آبيـارى كسر شده و در نتيجه در اين مزارع راندمان بالاتر بود.


تيمارهاى آبيارى موضعى ريشه با مباو •ه درصد تسنش آبسى، از

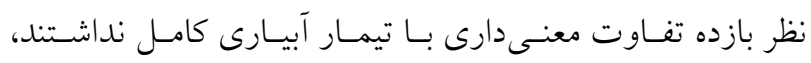


نفوذ عمقى كمتر و در نتيجه ذخيره بيشتر و بهدليل يـايين بـودن سرعت نفوذ، توزيع سريعتــ آب در سـطح مزرعسه را شـاهد و راندمان بالاترى ثبت شود.


بهرهبرداران، تـرويج اسـتفاده بهينـه از آب، توجيـه نيـاز آبسى و هم:جنين فقدان شركتهاى بهرهبـردار و نخهــار شـبكه جهـت لايروبى و اصلاح به موقـع خرابسىهـاى كانـالهـا و تأسيسـات وابسته اشاره كرد.
يايينتر اتفاق افتاده است كه عمله دليل آن تخريب ديـوارههـاى بتنى كانال، عدم آموزش بهرهبرداران و عدم تعميرات به موقع است. حداكثر راندمان كاربرد در مزارع مورد مطالعسه، 49 درصـد، حداقل مقدار آن، الب درصد و متوسـط رانــمان كـاربرد مـزارع مورد مطالعه، •ه درصد براورد شده است. همانطوركه از نتايج

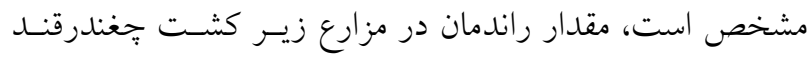

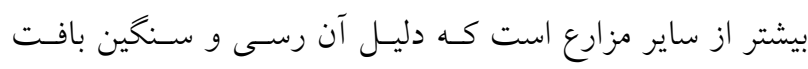
بودن خاك آن مزارع است كه باعث شده نسبت به سـاير مـزارع

\section{منابع مورد استفاده}

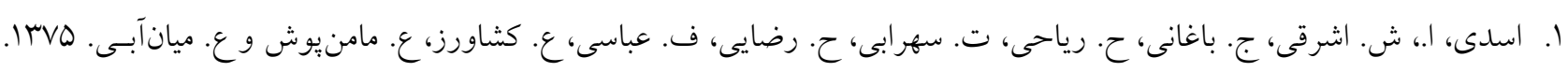
بررسى عملكرد روشهاى آبيارى سطحى تحت مديريت زارعين. مجموعه مقالات دومين كنخره ملى مسايل آب و خاك كشـور. تهران.

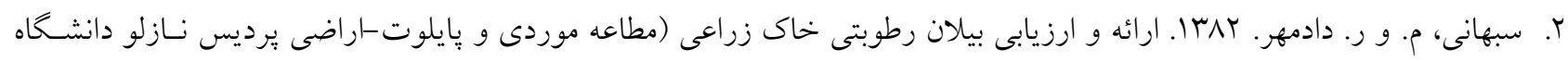
اروميه). يايانامه كارشناسى ارشد، دانشخاه اروميه، ايران.

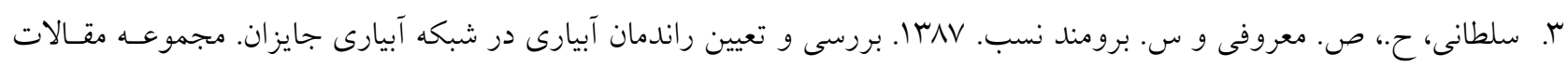
دومين همايش ملى مديريت شبكههاى آبيارى و زهكشى. دانشخاه شهيد تجمران اهواز.

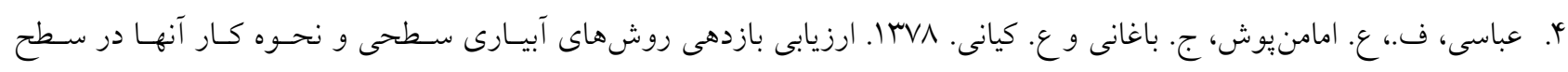

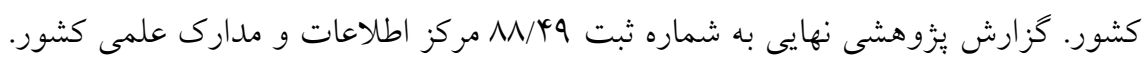

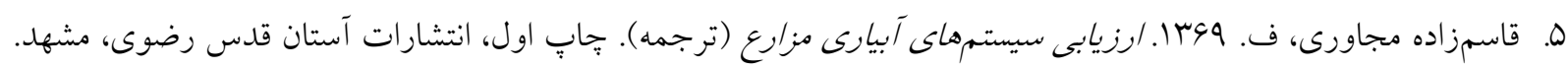

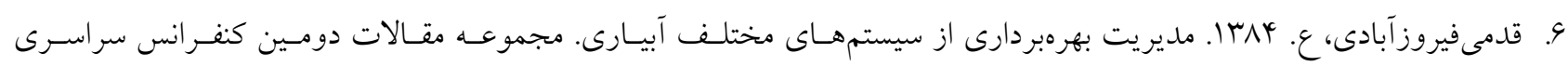

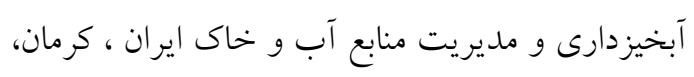

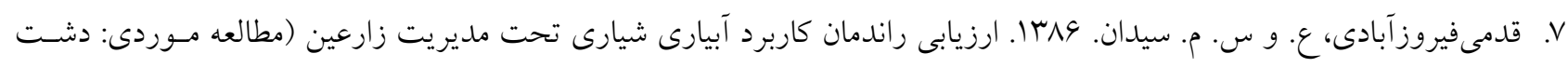

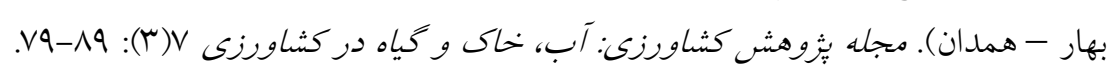

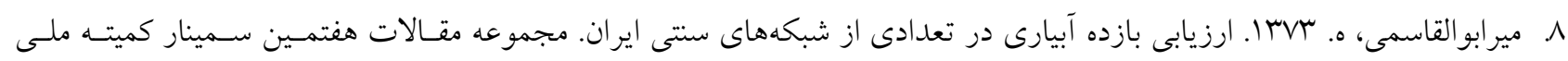

$$
\text { آبيارى و زهكشى ايران. تهران. }
$$


سيبزمينى در روشهاى آبيارى بارانى و قطرهاى - نوارى. مجله علوم و فنـون كشاورزى و منسبع طبيعى، علـوم آب و خهاك

$$
\text { KYI-YQO:(VI) } 19
$$

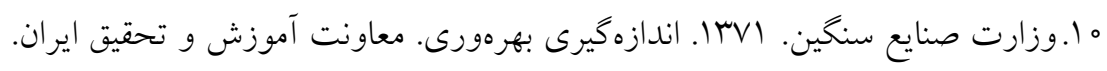

11. Ahadi, R., Z. Samanib and R. Skaggsb. 2013. Evaluating on-farm irrigation efficiency across the watershed: A case study of New Mexico's Lower Rio Grande Basin. Agricultural Water Management 124: 52- 57.

12. Awari, H. W. and S. S. Hiwase. 1994. Effect of irrigation systems on growth and yield of potato. Annual of Plant 
Physiology 8(2): 185-187.

13. Conrad, S. W., M. Dech, J. P. A. Hafeez, B. Lamers and B. Tischbein. 2013. Remote sensing and hydrological measurement based irrigation performance assessments in the upper Amu Darya Delta, Central Asia. Physics and Chemistry of the Earth 61: 52-62.

14. Galinato, G. D. 1974. Evaluation of irrigation systems in the Snake river fan. Jefferson, Contry, Idaho. MSc. Thesis, Idaho State University.

15. Kirda, C., M. Cetin, Y. Dasgan, S. Topcu, H. Kaman, B. Ekici, M. R. Derici and A. I. Ozguven. 2004. Yield response of greenhouse grown tomato to partial root drying and conventional deficit irrigation. Agricultural Water Management 69: 191-201.

16. Liang, Z., F. Zhang, M. Shao and J. Zhang. 2002. The relations of stomatal conductance, water consumption, growth rate to leaf water potential during soil drying and rewatering cycle of wheat (Triticum aestivum). Botanical Bulletin-Academia Sinica Taipei 43: 187-192.

17. Osman, H. El-B. 2002. Evaluation of Surface Irrigation Using Gated Pipes Techniques in Field Crops and Old Horticultural Farm. Agriculture Reserch Center, MOA, Dokki, Cairo, Egypt.

18. Payne, W. A. and M. C. Drew. 1992. Soil phosphorous availability and pearl millet water use efficiency. Crop Science 32: 1010-1015.

19. Ragab, R. A. 1983. The effect of sprinkler intensity and energy of falling drops on soil surface sealing. Soil Science 136(2): 117-123.

20. Yavuz, D., M. Kara and S. Suheri. 2012. Comparison of different irrigation methods in terms of water use and yield in potato farming. Journal of SelÄßuk University Natural and Applied Science 1(2): 1-12. 


\title{
Assessment of the Application Efficiency, Water Use Efficiency and Productivity of Irrigated Water in the Urmia Lake Basin (Case Study: Zarineh Rood irrigation and Drainage Network)
}

\author{
R. Jamali ${ }^{1}$, S. Besharat ${ }^{1 *}$, M. Yasi ${ }^{2}$ and A. Amirpour Deylami ${ }^{3}$
}

(Received: March 22-2017 ; Accepted: October 11-2017)

\begin{abstract}
The irrigation and drainage network of Zarrinehroud with an area of 65,000 hectares is the most important network of Lake Urmia basin, with the direct link to the lake. With the current crisis in the lake, an assessment of the existing network's performance is essential in the Urmia Lake Rescue Program. The purpose of this study was, therefore, to evaluate the transmission, distribution, and utilization efficiency and irrigation efficiency at the surface of the network. Three products were selected from the cultivar with the highest crop area (10\% beet, $22 \%$ and $22 \%$, and $38 \%$ wheat). The dominant method of irrigation was surface irrigation. At the network level, soil moisture in the field before and after irrigation, soil physical and hydraulic properties and water use volume for irrigation were measured. The results showed that the average transmission efficiency in canals with the concrete coating of the network was about $79 \%$, which was in the range of $33 \%$ (in the smaller channels) to $100 \%$ (in the larger channels). The water distribution efficiency in the network was, on average, $76 \%$, varying from $50 \%$ to $100 \%$. Water use efficiency in the fields based on soil moisture balance analysis varied from $41 \%$ in the sandy loam soils to $66 \%$ for the clay texture. Based on the analysis of the data on the amount of harvest, production costs and product sales price, the water use efficiency (in kilograms of product per cubic meter of water used) varied from 0.4 for the elderly hay to 5.1 for the sugar beet. The amount of water used in this network (in Rials per cubic meter of water consumption) was between 2740 for alfalfa aged over 10 years and 6900 for wheat. It can be concluded that in the case of water constraints, wheat, sugar beet and alfalfa could be the most economic cultivar, respectively.
\end{abstract}

Keywords: Surface irrigation, Irrigation efficiency, Productivity, Zarineroud Irrigation Network, Urmia Lake

1. Department of Water Engineering, Faculty of Agriculture, Urmia University, Urmia, Iran.

2. Department of Irrigation and Reclamation Engineering, Faculty of Agricultural Engineering and Technology, College of Agriculture and Natural Resources, University of Tehran, Karaj, Iran.

3. Department of Civil Engineering, Islamic Azad University, Urmia, Iran.

*: Corresponding Author, Email: s.besharat@urmia.ac.ir 